\title{
Tal Brasil, qual romance? Literatura não é documento. Sobre Ana Cristina César e Flora Süssekind
}

\author{
Jorge Wolff*
}

\begin{abstract}
Resumo: Ana C. e Flora, convivas e colegas de bancos escolares no universo acadêmico carioca da década de 70, ambas com um pé na universidade e outro no jornalismo, são abordadas criticamente a partir desse convívio e de dois ensaios resultantes dessa safra, Literatura não é documento e Tal Brasil, qual romance?, colocando-os em choque ou contraste e tomando como proposição-chave a noção devida a um teórico do cinema americano segundo a qual toda narrativa fílmica - e por extensão toda narrativa - é um "documentário".
\end{abstract}

Palavras-chave: Crítica brasileira. Neo-naturalismo. Neo-documentalismo. Flora Süssekind. Ana Cristina César. Literatura. Documentário.

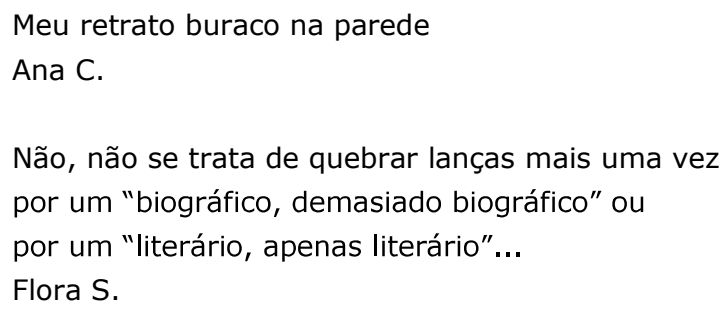

Naturalismo e neo-naturalismo, frequentemente usados como sinônimos de "documentalismo" e "neo-documentalismo", são termos simétricos a realismo e neorealismo (ainda que não possam ser considerados sinônimos) e que, ao mesmo tempo, remetem a seus opostos: fábula, ficção, e daí a fantasia, imaginação, as quais costumam, por sua vez, ser associadas de modo pejorativo ao que é falso ou mentiroso (cf. SAER, 1991: 2), em oposição ao que seria o real, quando não o próprio "realismo", seja ele de que tipo for, conforme o famoso artigo de Roman Jakobson (1970: 120): "Declaramos realistas as obras que nos parecem verossímeis, fiéis à realidade. E já se evidencia a ambiguidade...". Mas se o realismo, segundo a concepção marxista de um Nélson Werneck Sodré em O naturalismo no Brasil (1965), é o "problema fundamental da literatura", e o naturalismo "uma escola, entre outras" (SODRÉ, 1992: 53), o naturalismo especificamente "brasílico" - como foi ou tem sido lido pela linhagem da crítica abordada aqui - tornou-se uma espécie de segunda

* Doutor em Teoria Literária pela Universidade Federal de Santa Catarina e professor da mesma instituição. 
natureza da cultura brasileira, de sua identidade e de sua constituição como nação, transformando-se assim, a partir de fins da década de 70, no "problema fundamental da literatura".

Em um momento histórico em que a autonomia do campo da literatura deixou de existir, e em que os pilares da chamada modernidade (as certezas iluministas) sofreram um irreversível abalo, é necessário visitar certos arquivos da literatura e da crítica literária modernas do Brasil, com o intuito de rediscutir uma escala de valores quase inteiramente estabelecida com critérios esboçados nos textos do vanguardismo histórico, em detrimento da produção artística das décadas anteriores, tomadas, com raras exceções, como um bloco homogêneo submetido à noção de "academicismo". Fundamental, a vanguarda teve, é claro, suas muitas razões de ser, de ver e de agir, mas é preciso tentar pôr a nu o que foi rejeitado de modo generalizador, a partir da Primeira Guerra Mundial, como velho, romântico, parnasiano, simbolista, impressionista, naturalista, esteticista, decadentista ou, em uma palavra, "acadêmico". O ponto de partida é, portanto, a noção de documento conforme a linhagem historiográfica de Jacques LeGoff, questionadora tanto de monumentos quanto de documentos, fundamentando a presente leitura das abordagens de suas variantes narrativas e críticas na cultura brasileira desde o século XIX - sobretudo os chamados "surtos naturalistas", como os denomina Flora Süssekind (1984: 42), que em Tal Brasil, qual romance? investiga e problematiza uma "ideologia estética", ou os "surtos de cultura", nos termos bastante similares de Ana Cristina César (1999a: 13), que em Literatura não é documento relaciona literatura e cinema segundo um parti-pris claro desde o título.

LeGoff (1997: 103-4), no entanto, se posicionaria contra a idéia de que literatura não é documento. "Qualquer documento é ao mesmo tempo, verdadeiro incluindo, e talvez sobretudo, os falsos - e falso, porque um monumento é em primeiro lugar uma roupagem, uma aparência enganadora, uma montagem. É preciso começar por desmontar, demolir esta montagem, desestruturar esta construção e analisar as condições de produção dos documentos-monumentos". Como realizam esta tarefa as ensaístas Flora Süssekind - ao perguntar de modo questionador "Tal Brasil, qual romance?" - e Ana Cristina César - ao afirmar categoricamente "Literatura não é documento" - constitui nosso objetivo. Com as lentes próximas como nunca do que chamamos "realidade" desde meados do século XIX, algumas das principais vertentes narrativas ocidentais - apontam elas - vêm buscando se confundir com a "verdade indiscutível" supostamente contida no real, em novos modos de representação que decalcam o imaginário fotográfico e cinematográfico do período histórico conhecido como "modernidade".

Em A partilha do sensível (2005), Jacques Rancière - um teórico caro a Flora Süssekind - propõe que, ao invés dos modernismos e vanguardismos do início do século $\mathrm{XX}$, foi o advento do realismo e do naturalismo, por volta de 1850 , tanto em pintura como em literatura, que proporcionou o verdadeiro abandono da mímesis, dando lugar a uma outra lógica com o protagonismo do homem comum, com o fim das hierarquias temáticas e do privilégio das ações sobre os caracteres e da narração sobre a descrição. Assim, o rompimento entre "antigo" e "moderno" não estaria 
situado na transição do figurativo ao não-figurativo, ou do representativo ao nãorepresentativo, mas na época do surgimento do realismo, o qual, no seu modo de ver, "não significa de modo algum a valorização da semelhança, mas a destruição dos limites dentro dos quais ela funcionava" (RANCIÈRE, 2005: 35). Trata-se de uma tese controversa a qual, no entanto, pode ser tomada como uma consistente base teórica para reler o que, em troca dos decantados termos de "modernismo" e "vanguarda" conceitos insuficientes para dar conta do problema, segundo Rancière -, seria, desde então, o "regime estético das artes". ${ }^{1}$ Regime este que engloba precisamente a trajetória do naturalismo na cultura ocidental e suas viagens sem volta ao novo mundo. Parte deste universo complexo e avesso à fixação de datas e categorias, o momento das rupturas mais estridentes acabou por se concentrar no início do século $\mathrm{XX}$, mas só pode ser percebido enquanto produto de outros desvios anteriores, através de gestos e empreitadas tão rupturistas quanto as das chamadas vanguardas históricas, ainda que a partir de manifestações individuais, como as de Allan Poe, Baudelaire, Lautréamont, Wilde ou Mallarmé.

Com isso, postula-se um retorno ao século XIX, com ênfase na sua segunda metade, quando o ideal mimético e representativo explode em nome da apagamento das fronteiras entre o real e o imaginário nos modos de ver e fazer das artes em geral, em pleno século positivista e cientificista. São precisamente estas fronteiras que devem ser revisitadas de maneira mais crítica, uma vez que, se o ideal mimético "explode", ele ao mesmo tempo é recusado enquanto fissurado e fragmentário pela apropriação que o Estado costuma fazer desses modos de produção cultural, em sua obsessão pela manutenção da identidade, da semelhança, da simetria, conforme sugere Flora Süssekind, em seu estudo sobre o naturalismo brasileiro tomado como "ideologia estética".

\section{Tal Brasil, qual romance?}

A noção de naturalismo como sinônimo de documentalismo começa a se esboçar na obra crítica de Flora Süssekind no início da década de 1980 com a publicação de sua dissertação de mestrado, orientada por Silviano Santiago, embora inegavelmente já com voz própria no âmbito de uma nova crítica ativa tanto na universidade quanto no jornalismo. Do mesmo modo que ocorre na década de 1920 com o "modernismo heróico" brasileiro, o naturalismo - visto de modo estreito pelos seus arautos como meramente mimético, como cópia do real - é tomado pela ensaísta carioca como um mal a ser superado pelas mesmas razões que as vanguardas históricas o fizeram: tratava-se (e ainda se trata, no caso da ensaísta, conforme se verá) de combater no campo estético a idéia de representação literária enquanto "semelhança", "unidade especular", imitação da realidade. Assim, o alvo era (e é) todo o tipo de realismo lucaksiano entendido como representação "fidedigna" da realidade, em que a ficção se

\footnotetext{
${ }^{1}$ Em sua reconfiguração dos critérios estéticos ocidentais, Rancière (2005: 31-2) apresenta três regimes (vistos não como procedimentos artísticos mas como "regimes de visibilidade das artes"): o ético, baseado em Platão e restrito à antiguidade, o poético ou representativo, que segue com Aristóteles até o século XIX, e finalmente o estético, o qual incluiria a chamada "pós-modernidade".
} 
comportaria como um autêntico documento que atesta a veracidade dos fatos narrados. A fim de enfrentar esta "ilusão", Flora Süssekind lança mão das idéias de "fratura" e de "ruptura pela diferença", conforme as primeiras páginas de Tal Brasil, qual romance? (SÜSSEKIND, 1984: 20-21), que na seqüência do texto se repetirão como tais ou com o uso de termos similares como "corte", "desvio" e "fragmentação".

O fato de o título de sua dissertação apresentar uma interrogação aponta para o próprio gênero escolhido para desenvolvê-la, o ensaio, que se caracteriza, como é sabido, pelo privilégio da visão autoral em nome do questionamento dos objetos em estudo. Aponta também ao "tal qual" típico da tradição paternalista ocidental, traduzido como herança e reconhecimento mútuo, contra a qual arremete do início ao fim do texto, insuflada simultaneamente pela vanguarda brasileira - com sua reivindicação do matriarcado e da posse contra a propriedade - e pela "neovanguarda" da década de 1960 - com as lutas feministas e a liberação dos costumes. Aponta ainda para a problematização da própria identidade nacional enquanto algo homogêneo e indiscutível. O subtítulo do ensaio, "Uma ideologia estética e sua história: o naturalismo", faz eco a todo este repertório crítico, ao propor a sondagem de cerca de um século de produção literária dividido em três grandes "surtos" naturalistas: o da década de 1890, de linhagem positivista e cientificista, em forma de "estudos de temperamento", que responde ao impacto sobretudo das obras de Emile Zola e Eça de Queiroz, com Aluísio Azevedo à frente no Brasil; o da década de 1930, do chamado "romance social" de Jorge Amado, José Lins do Rego, Rachel de Queiroz e Graciliano Ramos, em forma de "ciclos romanescos memorialistas"; e o da década de 1970, em que a prática de um (in)certo jornalismo literário ou "romance-reportagem", entre o denuncismo e as páginas policiais, passaria a dar a chave para os usos da ficção, com destaque aos nomes de João Antônio, José Louzeiro e Aguinaldo Silva, romancistas da "realidade" brasileira em tempos de predominância dos meios de comunicação de massa - dos quais o último é, significativamente, um freqüentador bem-sucedido como roteirista de telenovelas.

O movimento da proposta central de Flora Süssekind - e a palavra movimento é empregada em função do ritmo "em onda" do ensaio, em que frases, idéias e citações se repetem e superpõem umas sobre as outras - reside, portanto, na oposição entre "semelhança" e "corte", através da analogia entre "família e estética". As primeiras sentenças do livro anunciam então: "A um filho parecido com o pai diz-se com orgulho: Tal pai, tal filho. Quanto maior a semelhança, maior a ênfase orgulhosa no tal que se repete". E ao final do parágrafo: "É a semelhança o que se aplaude ao dizer Tal pai, tal filho. O que importa é a garantia de reconhecimento de um no outro" (SÜSSEKIND, 1984: 21). Quando, porém, essa "unidade especular" sofre uma fratura, a família, a casa - para empregar o "cronotopo da intimidade" com o qual inicia o ensaio e que é a matriz do naturalismo brasileiro no século XIX - vem inteira abaixo: "Quando se quebra a homologia entre pai e filho, os elementos da máxima se invertem e ela se abre em dúvida: Tal filho, qual pai?" (idem, p. 22).

Com base nesta inversão, Süssekind desenvolve o ambicioso trabalho político de desvendar uma "ideologia estética", já que sua aposta se dá claramente em nome da fratura e do corte, desde o título, interrogativo e portanto crítico, inspirado na 
homologia pai-filho: Tal Brasil, qual romance? Em outras palavras, trata-se de questionar os fundamentos ideológicos do que se define como "literatura brasileira", e de propor uma polaridade entre permanência e impermanência, consonância e dissonância, noções as quais irá desenvolver opondo as metáforas espaciais do "círculo", própria do que chama de "repetição conservadora", e do "labirinto", em alusão ao que seria a "repetição diferencial" (cf. cap. 3, "Entre o labirinto e o círculo"). E quando faz referência, com ressonâncias marxistas, às "ressurreições do naturalismo" visto como "um sistema estético específico, e dotado de certa continuidade", o vê enquanto "fantasmagoria" recorrente: "Quando o espectro naturalista caminha outra vez, o diagnóstico não se tem feito esperar: 'neonaturalismo'"' (idem, p. 40). Süssekind só se permite utilizar o termo, no entanto, a partir da caracterização que Antonio Candido e Otto Maria Carpeaux haviam feito do romance de 30, assim como se apoiaria numa afirmação de Davi Arriguci Jr. em referência ao "surto" da década de 70, enquanto retorno à literatura mimética "com um lastro forte de documento". Aliás, o fenômeno se repetiria na literatura brasileira a partir dos anos 1990 até esta parte, quando a obsessão pelo realismo se dá não apenas na cultura do país mas do Ocidente em geral, com destacada força nos campos do cinema e da literatura. ${ }^{2}$ Pode-se, portanto, retomar as perguntas que introduzem o segundo capítulo do ensaio (e este sistema de perguntas é uma de suas virtudes), reinserindo-a no contexto atual:

\begin{abstract}
Por que certa estabilidade que possui o naturalismo em nossa história literária? Em que se assemelham e se distanciam tais "reedições"? O que se repete efetivamente no romance naturalista, na novela social da década de 30 e nos romancesreportagem dos anos 70? Em que se diferenciam? Que continuidades e diferenças se podem perceber nas repetições? (idem, p. 41)
\end{abstract}

Um dos confrontos mais significativos para desenhar o perfil crítico e as alianças de Flora Süssekind e os debates de sua geração se dá, em Tal Brasil, qual romance?, entre as figuras de Ferreira Gullar e Caetano Veloso, lidos em sua categoria de poetas (já que, segundo os critérios de uma crítica tradicional, só o primeiro o seria). Em tomada de posição ousada para a época, início dos 80, Flora Süssekind contrapõe um poeta consagrado, Gullar, a um trovador não menos apreciado (embora em outras instâncias), Caetano, com base nos respectivos poemas - ou "canções" - "Dois e dois: quatro" e "Como dois e dois" (idem, p. 112-114). A propósito dos "lugares-comuns indiscutíveis" de Gullar e da "lógica fraturada" de Caetano - que é como ela os enxerga -, é possível apontar a uma constante em seu modo de ver a literatura e a cultura brasileiras, que é o da eleição de um cânone desviado, bastante particular, mas de qualquer maneira um cânone sólido, junto a algumas apostas. Algo que

\footnotetext{
${ }^{2}$ A propósito, ver, por exemplo, os livros de Beatriz Resende, Contemporâneos: expressões da literatura brasileira do século XXI (2008), e de Diana Klinger, Escritas de si, escritas do outro. $O$ retorno do autor e a virada etnográfica (2007). No caso do cinema, o crescente interesse pelo documentário nas últimas décadas comprova essa tendência, sem falar nos recordistas de bilheteria Cidade de Deus e Tropa de elite. Sobre documentários no Brasil, ver, por exemplo, os livros de Cláudia Mesquita e Consuelo Lins, Filmar o real: o documentário brasileiro contemporâneo (2008) e O cinema do real (2005), organizado por Maria Dora Mourão e Amir Labaki.
} 
aparece claramente no breve texto "Não basta", publicado em 2003, em que ataca os inimigos "neo-documentalistas" sem nomeá-los e elenca seus escritores preferidos, com o Chico Buarque romancista à cabeça e o romancista Bernardo Carvalho como ponto de partida e de chegada. ${ }^{3}$ É contra essa "nova quadrilha" anônima que se desenvolve sua contenda estético-ideológica, tendo como "ilustração" do artigo o miniconto "Amigos e inimigos (ou nova quadrilha)", em que parodia um tipo de linguagem policial presente em textos de um João Antônio ou, mais recentemente, de um Paulo Lins.

A ensaísta carioca, que inicia a sua trajetória crítica entre Silviano Santiago e Roberto Schwartz, ${ }^{4}$ continua, portanto, século XXI adentro, com o seu obsessivo combate ao "neo-naturalismo" ou "neo-documentalismo" na cultura brasileira. Em um estudo panorâmico apresentado na Universidade de Oxford em 2002, "Desterritorialização e forma literária - Literatura brasileira contemporânea e experiência urbana", Flora Süssekind retoma as idéias expostas em seu livro de estreia e volta a criticar, em nossa prosa recente, a multiplicação de "testemunhos diretos", "histórias de vida" em forma de "escrita para-jornalística" e de "catalogação patológico-criminal" (SÜSSEKIND, 2002: 1-4), opondo - e aqui dando nome aos bois Ferrez, Dráuzio Varella e Paulo Lins a João Gilberto Noll, Zulmira Ribeiro Tavares e Nélson de Oliveira, entre outros. Do mesmo modo, no artigo mencionado acima, escrito para um revival da revista esquerdista Argumento, irá retomar o seu combate com base em Bernardo Carvalho, cuja obra toma como exemplo de anti-naturalismo crítico (valha a redundância) contra a "nova quadrilha" - na denominação retirada do texto de Carvalho que parodia a linhagem policial-jornalística da literatura nacional (SÜSSEKIND, 2003: 16-17). Para ir direto ao ponto, com dois exemplos exemplares: o autor de $O$ filho da mãe contra, ou à diferença, do autor de $O$ filho eterno. ${ }^{5}$ Chama a atenção que os "novos quadrilheiros" não sejam mencionados diretamente, à diferença do texto apresentado em Oxford e ao contrário dos anti-naturalistas de linhagem "graciliano-machadiana", cânone singular, idiossincrático que inclui, no artigo publicado no Brasil, além de Buarque e Carvalho, Valêncio Xavier, Sebastião Nunes, Joca Terron, Carlos Süssekind de Mendonça, Francisco Daudt da Veiga e o contista Silviano Santiago de $O$ falso mentiroso (2004).

Quanto à ousadia da escolha de Caetano Veloso como objeto de análise enquanto autor de poesia em Tal Brasil, qual romance?, explica-o o mero gesto de contrastar um texto conservador de um intelectual de tradição comunista com uma canção de um artista pop tropicalista, cuja escrita é comparada àquela fragmentária de Oswald de Andrade, onde está "tudo certo como dois e dois são cinco" (SÜSSEKIND, 1984: 113). Conforme seu uso, a ensaísta conclui sua tomada de

${ }^{3}$ É importante observar que Flora Süssekind se refere ao escritor Chico Buarque em sua faceta, digamos, "pós-moderna", da série de narrativas dos anos 90 em diante, e não ao dramaturgo engajado dos anos 70. Quanto a Bernardo Carvalho, é assumido como modelar todo o seu programa de uma literatura crítica, com a ajuda de uma reflexão estética igualmente adorniana esboçada em artigos de jornais, reunidos em $O$ mundo fora dos eixos (2005).

${ }^{4}$ O que talvez possa ser lido como um sintoma da própria tensão entre essas duas vertentes críticas, já que chama a atenção a própria menção acrítica do Schwarz de "As idéias fora do lugar" feita por Flora em seu ensaio (cf.: 42).

${ }^{5}$ O livro de Carvalho aparece em 2009; o de Tezza, em 2008. Ambos retomam, cada um a sua maneira, o tema da morte do filho presente no início de Vidas secas. 
posição, digamos, pró-tropicalista, retomando alguns protagonistas de sua série de escritores de eleição. Retornam, então, ao lado de Caetano - que, contrariamente a Gullar, instalaria o estranhamento e a dúvida no discurso - os nomes exemplares de Graciliano Ramos, Domingos Olímpio, Renato Pompeu e o próprio Émile Zola, visto como mais antinaturalista que muitos antinaturalistas:

\begin{abstract}
Trocar o resultado da soma é, de certa forma, pelo estranhamento, mostrá-la como coisa discutível, como lugar-comum. Ela se transforma em lugar de dúvida e não de univocidade e segurança. É como se Caetano se utilizasse da analogia ("como 2 e 2"), do "tudo certo", mas para desmenti-los ("cinco"). Como faz Graciliano Ramos com o projeto de "divisão do trabalho" em São Bernardo. A simples enunciação do projeto pelo narrador Paulo Honório se faz acompanhar de seu desmoronamento. Como em Luzia-Homem a comparação à teatralidade de um quadro retira do romance a possível ilusão de veracidade tão cara ao naturalismo. Como em Quatro olhos o simples fato de se saber que o personagem escreve um livro e vê o mundo através de um olhar em duplicata afasta o romance de Renato Pompeu das narrativas jornalísticas suas contemporâneas. Nesses casos parece que ao leitor se traz a inquietante estranheza de metamorfosear números em letras e estigmatizálos com a condenação de Zola: "a dúvida permanece eterna". (idem, p. 114)
\end{abstract}

Da argumentação acima parece necessário relativizar ao menos o exemplo do romance de Domingos Olímpio, cuja menção a um quadro de Rembrandt antes reforça a ótica naturalista ao descrever em minúcias um ambiente no qual havia um quadro de um pintor célebre. A grande "fratura" em relação a Luzia-Homem (1903) está em outro lugar, está na figura da "donzela-guerreira", conforme vê a própria ensaísta, que destaca igualmente a substituição do imaginário das ciências naturais nesse romance pelo da sabedoria popular, algo raro entre os relatos naturalistas brasileiros do século XIX. Mas esta mulher jovem e casta é transformada em algo mais do que simples protagonista de mais uma história sobre a seca de 1877: Luzia-Homem (denominação que manifesta clara ambigüidade em meio à obediência e castidade) seria antes uma heroína romântica tradicional, com o seu devido fim trágico. Contudo, se trata de uma heroína que é ao mesmo tempo uma criatura fantástica caracterizada como extraordinariamente dotada, mais forte que os mais fortes com seus "músculos de aço", a qual foi vista carregando "uma parede" por um viajante francês que tomava notas, ${ }^{7}$ e que finalmente é atacada e morta por um personagem monstruoso e cruel, encarnação do mal na modernidade.

No entanto, observa Flora, não seria questão "de repartir a literatura brasileira em grupos antagônicos. Em naturalistas ou não. Em bandidos e mocinhos", e sim de verificar "que caminhos e transformações estéticas e ideológicas segue esse naturalismo", de procurar o labirinto, a diferença "pelas trilhas de uma repetição circular" (idem, p. 114-15). Apesar desse cuidado, a crítica nem sempre consegue afastar essa impressão de "divisão em grupos antagônicos" (como nos textos recémmencionados), a ponto de se sentir obrigada a justificá-la logo após contrapor duas

\footnotetext{
${ }^{6}$ Em carta a um amigo, escrita em 1864, Zola expunha sua "théorie de l'écran", segundo a qual a percepção da realidade nunca se dá de forma direta mas através de uma "tela", "personalidade" ou "temperamento": "A realidade exata é impossível na obra de arte", já dizia então, apesar de sua busca obsessiva pela "verdade" (cf. ZOLA, 2006: 413).

7 Menção à "realidade" que busca injetar verossimilhança na narrativa, ao modo do "efeito de real" barthesiano.
} 
posições estéticas e políticas de dois nomes - Gullar e Caetano - atuantes naquele momento e até os dias de hoje no cenário cultural brasileiro. Mas se o caráter fantasmagórico de Luzia-Homem não é destacado como traço anti-naturalista em Domingos Olímpio, a fantasmagoria ou o simulacro próprios à "ideologia estética naturalista", retornam agora no final do quarto capítulo com o exemplo de $L a$ invención de Morel (1940), de Adolfo Bioy Casares, cujo mundo é duplicado por uma máquina capaz de capturar "imagens filmadas" inventada pelo protagonista - que, como no "Homem de areia" de Hoffmann, se apaixona por um simulacro de mulher. A ensaísta se apropria então dessa máquina discursiva sem fronteiras (que desembocaria no Ano passado em Marienbad de Alain Resnais e no limite em Bem longe de Marienbad de Caio Fernando Abreu) ao interpretá-la como metáfora da máquina naturalista:

\begin{abstract}
Como na máquina inventada por Morel, a transformação de objetos em imagens cristaliza-os, retira-Ihes o caráter de acontecimentos. E implica, de certa forma, como observa Susan Sontag, "um conhecimento e uma aceitação do mundo tal como a câmara o registra". A imagem apenas comprova e repete um real. A ela não parece caber o poder do não, de desmontar aquilo que reduplica, de transformar os objetos de que se apropria. Por isso aos fantasmas de Morel cabe uma repetição inexorável. Por isso a obsessão naturalista pelo retrato fiel. Ao invés de negar a realidade histórica representada ficcionalmente, o naturalismo acaba por fixar o mundo enquanto imagem. Não funciona como um convite iconoclasta à mudança histórica. (idem, p. 116-17 - grifo da autora)
\end{abstract}

Cabe insistir no fato de que a imagem, ao ser absorvida, tende a ser fixada pela "ideologia estética dominante" enquanto certeza, enquanto comprovação tranqüila e indiscutível do que o olho vê, enquanto documento no sentido épico, ou "morto", de "monumento" (segundo Le Goff), depositário de verdade e autenticidade absolutas, seja ele um monumento visual ou escrito. Tudo o que eles - imagem, texto, documento - definitivamente não são. O que a autora tampouco deixará de notar, ao apontar para o seu caminho crítico:

Nem a repetição, nem o naturalismo, entretanto, pertencem necessariamente ao império da identidade e da circularidade (...). É possível que, a repetições circulares e simétricas, se interponham textos que, com semelhante projeto naturalista, dêem margem ao labirinto, à assimetria e ao corte. (idem, p. 117)

La invención de Morel, em que o "narrador-espectador" entra em cena e rompe com a verdade daquelas imagens, é a seu ver modelar, tanto por exaltar a condição ficcional de todo discurso como por criar a metáfora ideal para a "lógica das repetições", seguida à risca por Flora Süssekind, a fim de "mudar o rumo", "procurar outras saídas" (idem, p. 119) ou buscar - à maneira das vanguardas modernas - o novo. Afinal, "quem acredita na veracidade da imagem não será capaz de transformála". Residiriam nisto, portanto, os males do Brasil, já que a ideologia naturalista é não apenas "especialmente valorizada pela cultura brasileira", como é igualmente "paradigma crítico e estético de alguns dos textos e autores de maior sucesso em nossa história literária" (idem, p. 119). Conforme se sabe, é assim que a autora compreende o naturalismo aclimatado nos trópicos: como paradigma crítico e estético que se mantém inalterado desde as últimas décadas do século XIX. 
Nas palavras finais do ensaio, ela torna a apresentar o seu cânone particular e a insistir na necessidade de um naturalismo que se autossabote, que corroa por dentro os "seus estreitos moldes", o que equivaleria a afirmar que a predominância avassaladora do desejo de continuidade, de simetria e de sentido na cultura brasileira é uma doença a ser superada mediante o esgarçamento sem limites da linguagem, em nome da ruptura e da diferença - precisamente como nos tempos das vanguardas históricas:

\begin{abstract}
O naturalismo repete, reduplica utopias. $E$, com isso, não abre espaço para a transformação, para a História. O que só pode ocorrer numa literatura-lâmina, numa literatura-contra. Em textos como os de Machado de Assis, Oswald de Andrade, Guimarães Rosa, fora das molduras naturalistas. Ou, como os de Domingos Olímpio, Graciliano Ramos, Renato Pompeu, que, de dentro do naturalismo, o fraturam e realizam saltos dialéticos para fora de seus estreitos moldes, de suas obsessivas analogias. Em direção ao humor, à descontinuidade, ao corte. A uma literatura só-lâmina. (idem, p. 198).
\end{abstract}

A resistência literária modernista contra o demônio do naturalismo parece, porém, ter o poder de se dissolver ao se disseminar, já que permanece tão enraizado e influente, o que parece mostrar que o naturalismo "brasílico" é o mito por excelência da cultura nacional, e a repetição conservadora a sua segunda natureza. Tal como Roland Barthes o descreveu precocemente em suas Mitologias (1957), ${ }^{8}$ o mito (ainda) hoje é uma fala marcada pela tautologia e pela reafirmação do senso comum, a qual continua a recobrir como uma pesada nuvem as formas de ver e de fazer do universo simbólico ocidental.

\title{
2. Literatura não é documento
}

A questão central de Tal Brasil, qual romance? - que visão do estético-literário se dissemina no país - está na ordem do dia durante os últimos anos da ditadura militar, que se caracteriza por ser um período de distensão social relativa e revisão ideológica geral. Conforme o espírito do tempo há, nesse questionamento, uma intenção ou preocupação pedagógica própria do impulso renovador que move as "exceções à norma" naturalista, preocupação à qual o ensaio de Flora Süssekind cede mais do que deixa transparecer através da marca da "estética da recepção". ${ }^{9}$ As formas de leitura dos relatos analisados no ensaio são destacadas pela voz dos próprios escritores, seja em entrevistas, seja em prefácios e outros paratextos, ao comentarem os próprios escritos. Grande parte dos ataques aos projetos literários de, por exemplo, Jorge Amado ou João Antônio se dá através do que eles dizem sobre os textos, e não exatamente sobre os textos. Ao contrário, quando se trata de destacar os desvios ao naturalismo dominante, são os textos mesmos dos escritores de sua eleição que se fazem ouvir - de João Guimarães Rosa, Carlos Drummond de Andrade e Graciliano Ramos a Renato Pompeu, Loyola Brandão e Chico Alvim.

\footnotetext{
8 "Presença ausente" no ensaio, que cita apenas A câmara clara de Roland Barthes.

${ }^{9}$ Mencionada explicitamente uma vez a propósito da idéia de "recepção quase-pragmática" - que não seriam percebidos nem como pragmáticos, nem como ficcionais - devida a Karlheinz Stierle, em texto da coletânea $A$ literatura e o leitor: textos de estética da recepção, coordenada e traduzida por Luís Costa Lima em 1979.
} 
Como se define a literatura, tomada enquanto sintoma dos modos de ver e fazer de uma determinada cultura nacional que se poderia chamar também "quasepragmática", estando situada pragmaticamente entre o documental e o monumental, é assim a pergunta que está no ar no panorama intelectual brasileiro modernizante e universitário de fins da década de 70. É a mesma pergunta que se faz Ana Cristina César em sua dissertação de mestrado, intitulada precisamente Literatura não é documento, realizada entre 1977 e 79 sob orientação de Heloísa Buarque de Hollanda, o qual viria a ser oficialmente o seu primeiro livro publicado, após a edição autoral de Cenas de abril. A investigação, feita ao migrar do mestrado em Letras da PUC para o mestrado em Comunicação da UFRJ, a fim de seguir trabalhando com Heloísa, de quem se assume discípula (cf. MORICONI, 1996: 72), voltou-se para as relações entre cinema e literatura no Brasil, do mesmo modo que sua mestra, cuja dissertação tinha sido dedicada, por sua vez, à adaptação de Macunaíma feita por Joaquim Pedro de Andrade em 1968. O estudo teria a sorte e o mérito de aparecer em livro já no ano seguinte, em edição do Ministério da Educação via Funarte. ${ }^{10} \mathrm{Na}$ introdução, datada de janeiro de 1979, a autora trata de explicitar o seu objeto e o seu objetivo:

Esse "objeto" não são propriamente os filmes a que andei assistindo, mas sim os conceitos ou representações do literário que esses filmes, explícita ou implicitamente, acabam utilizando. Que definição de literatura, que visão do autor literário são postas em circulação por esses filmes? (CÉSAR, 1999a, p. 13).

Ana Cristina César propunha, portanto, a análise dos "surtos" documentais do país - ao modo do que Flora sistematizaria logo depois em seu ensaio. ${ }^{11}$ No caso de seu corpus fílmico, esses surtos foram insuflados por diferentes gestões totalitárias do estado brasileiro durante o século $X X$ : "o surto de cultura patrocinada pelo Estado Novo, o projeto cultural militante de esquerda que se intensificou nos anos 60 e o novo surto de cultura patrocinada que parece pegar no governo Geisel" (idem, p. 13). Como se constrói uma certa imagem do país, com base em sua produção cultural, é, portanto, a questão que compartilham Ana Cristina César e Flora Süssekind, ambas preocupadas em radiografar criticamente a ideologia estética naturalista, sob a égide de Heloísa Buarque de Hollanda e de Silviano Santiago, respectivamente, cuja sintonia intelectual de longa data, ligada a uma certa leitura do pós-estruturalismo e dos estudos culturais no Brasil, se mantém até hoje. Se no final do século XIX, quando se instala o naturalismo no país, é a fotografia que está no imaginário da população e faz refletir sua "revolução documental" nos padrões estéticos do momento, no século XX o cinema substitui ou complementa esse imaginário com a mesma duplicação da vida, agora em movimento. Acompanhando a trajetória filosófica e política do Ocidente na

10 "Me manda minha pesquisa quando sair", escreve Ana Cristina a Heloísa da Inglaterra, onde foi estudar Sociologia da Literatura ("por que foi mesmo que eu inventei esse curso e não outra bobagem qualquer?") mas acabou fazendo um Mestrado em Tradução ("Traduzimos poemas e aí discutimos o que foi que aconteceu. Uma maneira muito incrível de discutir teoria"). As citações pertencem a cartas para Heloísa, de março de 1980 (a primeira) e de outubro de 1979 (as demais), reunidas em Correspondência incompleta (1999b, p. 42, 31 e 36).

${ }^{11}$ Após a morte precoce de Ana Cristina César em outubro de 1983, Flora Süssekind teria acesso aos "documentos" deixados pela poeta, entre poemas e rascunhos de poemas, traduções, anotações e diários, e com base neles escreve o ensaio Até segunda ordem não me risque nada, publicado em 1995, que investiga a oralidade e a polifonia em sua poesia. 
"era dos extremos", os governos - e também a oposição a eles - tomam para si a tarefa de documentar essa vida desde um determinado ponto de vista, de ditadura em ditadura. Da primeira ditadura de Vargas em 1937 à ditadura militar fundada com o golpe de 1964, no caso de Ana Cristina César; da campanha pela abolição da escravatura e a proclamação da República às décadas de 1930 e 1970, no caso de Flora Süssekind.

Além dessa proximidade em relação a tempos e motivos, vale atentar para a maneira como Ana Cristina César se refere aos documentários sobre literatura financiados por esses governos - primeiro, entre 1939 e 1949, com o cineasta Humberto Mauro à frente da máquina cinematográfica do Estado Novo, e depois com a Política Nacional de Cultura dos militares a partir de 1964: trata-se, por um lado, de investigar a "definição de cultura nacional que o Estado tem procurado formular", outorgando-a autoritariamente desde o século XIX, e, por outro, de analisar as formas de "desafinar o coro", conforme o capítulo homônimo que conclui sua "pesquisa" (como ela a chama). Neste capítulo, afirma a autora, pretende-se

\begin{abstract}
levantar não os filmes que dão a volta por cima com pureza mas sim as brechas que alguns deles introduzem num sistema dominante de representações ideológicas, que inclui os conceitos de "filme documentário, cultural ou educativo", "literatura", "autor literário/artista" e "nacionalidade cultural". (idem, p. 12-14; grifo meu)
\end{abstract}

Onde se lê "brecha", leia-se "corte", "fratura", "divisão", "desvio", "ambiguidade", "dúvida", "fragmentação", "diferença", que vêm a ser os termos que formam o repertório crítico empregado por Flora Süssekind do início ao fim de Tal Brasil, qual romance?, ao referir-se às possíveis saídas da ideologia naturalista conservadora predominante no país. E esta também é investigada com base na questão autoral e na da nacionalidade cultural, como em Ana Cristina César , tendo como fundamento a lógica do autoritarismo patriarcal, que preenche de sentido, utilizando-se dos "truques" ou "band aids" naturalistas (SÜSSEKIND, 1984: 174), o que é marcado pela diversidade e pela heterogeneidade. Sendo assim, o que os dois ensaios enfocam é, na verdade, um modo estreito e interessado de ler a cultura brasileira, a partir de critérios que vêem o "documental" enquanto o meramente fotográfico, mera reprodução da realidade e da verdade - seguindo o receituário positivista e cientificista forjado no século XIX, sem considerar "as ligações entre literatura e documentário de modo bem mais crítico" (idem, p. 187; grifo meu). Esta maneira de abordar seu próprio corpus, nas derradeiras páginas do ensaio, em que fica explícita a necessidade de relativizar e problematizar o valor concedido a um e outro (literatura-ficção, documentário-documento), merece ser destacada contra a cristalização da visão que prefere tomar a noção de documento como um todo fechado e invulnerável, que é, como se sabe, a visão tradicional que deliberadamente o confunde, enquanto "ideologia estética" (no sentido marxista de ideologia), com realidade e verdade. Ainda assim, talvez coubesse perguntar se a insistência em enxergar a "visão oficial" como meramente homogeneizadora e objetivadora não termina por acentuar o caráter de ilusória transparência daquilo que é antes "simulacro" ou "fantasmagoria", conforme Flora Süssekind tampouco deixaria de observar: 
Tentando dar conta fotograficamente de um país, ele mesmo envolvido num projeto de aproximação a modelos (culturais ou não) estrangeiros, a literatura fica ainda mais longe de seu desejo mimético. Em busca de um modelo que, por sua vez, também tenta reduplicar outro, mais parece tratar-se de uma casa de espelhos, onde todos querem refletir uma imagem que, de sua parte, é igualmente o reflexo de outra. E a estética naturalista acaba se convertendo em fantasmagoria, perseguição a uma realidade que não percebe ser também um simulacro. (idem, p. 39)

Certamente o problema deve ser visto com outros olhos no presente, quando o próprio conceito de nação vive um outro avatar, mas naquele momento de polarização política e de busca desesperada por saídas a essa polarização, tampouco a visão oficial parecia apresentar brechas. Em todo caso, a noção convencional de documento e documentário prevalece igualmente no levantamento feito pela pesquisa de Ana Cristina César, já que em seu caso se trata de problematizar objetos culturais - os filmes - cuja caracterização é frequentemente mais rígida do que a de outros campos da cultura, por ser uma atividade artística ao mesmo tempo técnica e industrial, que depende sempre de aporte financeiro considerável (ao contrário do livro), e por depender do patrocínio de governos totalitários. Assim, os filmes documentários vistos por Ana Cristina

têm de se haver com a função instrutiva, que aparece desde a origem do cinema documentário ligada à sua própria natureza de "reprodução" (não ficcional) da realidade. O cinema documentário deve documentar para ensinar. Documentar já é ensinar, mostrar, divulgar, esclarecer. (CÉSAR, 1999a: 15)

De modo que se poderia, a partir disso, reformular a compreensão da noção de documentário em Ana Cristina César, colocando-o em termos de uma "estética da recepção" (conforme o fizemos com Flora Süssekind): em primeiro lugar, como tais filmes são vistos?; em segundo lugar, por que tais filmes são predominantemente vistos "tal qual", ou seja, como apenas tranquilizadores e edificantes, ou (para emprestar a terminologia de Stierle) "quase-pragmáticos"? Cabe lembrar, por outro lado, que o cinema é desde a sua origem inteiramente voltado à "documentação" da realidade. Vistos dessa forma, cinema e documentário são termos que se correspondem intimamente, a tal ponto que um teórico do cinema norte-americano decidiu iniciar sua Introdução ao documentário com a máxima: "Todo filme é um documentário", para em seguida dividir esses documentários, didaticamente, em dois tipos: aqueles que representam as paixões humanas, aos quais se costuma chamar de "fiç̧ões" e ligar ao mero entretenimento, e aqueles que fazem representações sociais, os chamados (de modo redundante) "filmes documentários", que se costuma ligar à educação e à informação. Porém, ressalva Nichols, consciente da complexidade da questão, estes "tipos" aparecem frequentemente mesclados um ao outro no cinema, na literatura e nas artes em geral (NICHOLS, 2001: 21-22).

Salvo algumas exceções, não é o que se vê na filmografia de Ana Cristina César, em que predominam filmes que tendem a ser tomados como simples "Cromos do país", segundo o título do primeiro capítulo, uma vez que representam "valores nacionais" - os grandes escritores brasileiros vistos como reflexos heróicos da nacionalidade - amplamente disseminados "nos meios escolares, nas instâncias de consagração de cultura, nos meios de comunicação de massa" (CÉSAR, 1999a: 15). A 
divisão que propõe para a análise, entre "produções independentes" e "produções fetichizantes", também é similar à de Flora Süssekind, que - como se viu - a sofistica através do emprego das metáforas do "círculo", para estas, e do "labirinto", para aquelas. E logo aponta para uma indecisão em relação a essa divisão, a propósito de um filme híbrido ou inclassificável de Júlio Bressane:

\begin{abstract}
De um lado, os filmes que traduzem uma concepção oficial, escolar, exaltadora de personalidades, através de uma linguagem conservadora e da ênfase nos dados biográficos. Do outro uma produção que pretende penetrar e interpretar o universo literário, deslocando a figura do autor do centro das atenções e pondo em cena algum tipo de relação com o texto literário. E fica num certo limbo uma produção que não se encaixa bem nem em uma nem em outra, porque parece esposar um pouco de cada uma, como o Lima Barreto. ${ }^{12}$ (idem, p. 18)
\end{abstract}

Costumam ser essas precisamente as "exceções" presentes no contra-cânone de Flora Süssekind, as narrativas híbridas no sentido de manifestarem seu ser ficcional ao contarem histórias "reais", como o fazem ou fizeram os escritores Graciliano Ramos, Silviano Santiago ou Bernardo Carvalho. Relativizando o problema do dirigismo cultural, embora considere que "o aproveitamento ideológico do registro poderá ser até inevitável", Ana Cristina César assevera que "o documentário interessa como promoção de uma política porque fixa imagens, registra a carinha do autor, o monumento nacional". Documentos monumentais, os filmetes de escritor brasileiro feitos para o Estado são, contudo, desmistificados pela poeta e pesquisadora carioca, ao definir com precisão o que significa, a seu ver, a bem-sucedida "ilusão documental", e o não menos corriqueiro "mito da objetividade" - o que faz com contundência:

\begin{abstract}
A questão que não se considera é que todo documentário, mais do que falar de um objeto que Ihe é externo, fala fundamentalmente da relação entre o seu produtor e seu objeto. Articula uma visão sobre esse objeto e não capta a sua realidade pura. A ilusão documental consiste em ler o filme documentário como aquele modo fotográfico que mantém, mais fiel do que qualquer outro, a integridade do real, que deixa a realidade mostrar-se a si mesma sem intervenções. É no documentário que a literalidade da fotografia vem à baila com mais força. É como se estivéssemos diante do próprio real, duma analogia perfeita, duma pura denotação. O mito da objetividade é reforçado pela proposta documental, que sabe bem encobrir a sua manipulação. (idem, p. 20; grifos da autora)
\end{abstract}

Na seção "Uma linguagem só-transparência" de Tal Brasil, qual romance?, o discurso é novamente convergente em sua urgência, sintoma de uma geração de críticos-escritores que se formou sob a censura, a violência e o silêncio. Representantes de uma literatura crítica de combate antes rebelde que revolucionária, críticas literárias e culturais atuantes através de análises que se querem desmistificadoras e iluminadoras, além de "distendidas" (dado que permite demarcar melhor sua posição em tempos de modernidade tardia, repressão e desbunde), as ensaístas apelam a um vocabulário em tudo sintonizado. Enquanto Ana Cristina César fala em "função documentário", "função autor" (de clara raiz foucaultiana, não mencionada) e "conceito de cultura nacional", a propósito dos "pressupostos

\footnotetext{
${ }^{12}$ Filme de Júlio Bressane realizado em 1970.
} 
indiscutíveis" que regem a lógica dos filmes sobre autor nacional, Flora Süssekind arrola três tipos de identidade inexpugnáveis segundo a visão naturalista: a identidade patriarcal - que se quer "band aid" contra qualquer desvio; a identidade autoral - que vende um conceito harmonizante de cultura e história através de personagens ilustres; e a identidade nacional, o todo não menos harmonizante de uma idéia de nação una e indivisível que não passa de "utopia" ou "simulacro" (SÜSSEKIND, 1984: 43).

Uma das perguntas significativas que Flora Süssekind se faz nesse momento é: "Por que apenas uma identidade estética naturalista constitui sistema na literatura [e, por extensão, cultura] brasileira?" (idem, p. 42). Criticando os mitos da objetividade e da pura denotação nos mesmos termos, ao colocar esta pergunta a ensaísta emenda uma declaração do escritor Adonias Filho (outro de seus alvos), em que ele vincula o romance brasileiro precisamente ao documentário enquanto narrativa que não se indaga como linguagem: "O país nele pode encontrar a sua identidade. E pode encontrá-la sobretudo porque, em estado de testemunho, guardando as imagens como em um espelho, não anula em sua fixação as percepções dos romancistas". Diante do que, ela conclui: "A estética naturalista funciona no sentido de representar uma identidade para o país, de apagar, via ficção, as divisões e dúvidas" (idem, p. 43). No texto de Ana Cristina César pergunta-se, por sua vez: "Seria possível introduzir diferenças no interior do sistema documentário/autor literário/cultura nacional?" (CÉSAR, 1999a: 21). Nesse posicionamento crítico simétrico, é muito salutar e saliente a busca por uma "terceira via", por uma saída em relação à polarização política entre direita e esquerda, lúcida e avançada para a época, já que escreviam no olho do furacão. Ao tentar responder à própria questão, a autora de Literatura não é documento evita resolvê-la de modo simplista através do dirigismo cultural, seja ele provocado por razões financeiras ou ideológicas:

\begin{abstract}
Um produto diferenciado não se explica por sua relação coerente com uma cobertura financeira independente ou precária. Não se explica tampouco pela "oposição ideológica" que instaura contra o "Poder", ou seja, por uma ideologia dominada que se contrapõe a uma dominante. Mais ainda porque, em termos de cultura brasileira, o conceito oficial e o conceito das esquerdas anda mais próximo do que se pode imaginar. As esquerdas constituídas também não têm posto em dúvida a função missionária, educadora, que se materializa com justeza no documentário padrão, dados conteúdos esquerdizantes. Se é possível localizar filmes diferenciados no interior da produção de documentários sobre literatura, seriam filmes que produzem tensões específicas no sistema que parece prédeterminá-lo: tensão entre a subvenção oficial e a discussão da visão oficial; entre a pressuposta missão educativa do documentário e elementos que rompem o aparato didático-objetivo ou didático-comovedor; entre esses elementos e a aliança que todo documentário estabelece com seu público (esclarecer, mostrar); entre o educativo (dar aula sobre um autor) e o interpretativo (trabalhar sobre textos). Não sei se algum desses filmes consegue eliminar estas contradições e situar-se com pureza no lugar da Contestação. (idem, p. 21; grifo meu)
\end{abstract}

No entanto, como se trata também ela de uma iniciativa pedagógica e militante, ainda que no sentido das "micro-revoluções", é necessário procurar narrativas fílmicas que possam produzir "resistências", cuja adjetivação em cascata proposta por Ana Cristina César é igualmente sintomática do novo discurso crítico daquele período: não se trata de resistências quaisquer e, ao mesmo tempo, amalgamam-se todas as suas espécies e subespécies então em tensão, "resistências possíveis, necessárias, 
improváveis, espontâneas, planejadas, irreconciliáveis, prontas ao compromisso, interessadas, fadadas ao sacrifício etc." (idem, p. 22). Adjetivação que aponta, além do mais, para o canto do cisne, a agonia das forças políticas de esquerda ou de direita, que disputavam de maneira igualmente inócua o poder sobre o significante revolução.

\section{Tal Brasil, qual documento?}

Entre a reforma e a revolução, o documento e o monumento, a fantasmagoria e o simulacro, conclua-se inconclusivamente com a seguinte questão: se, a se crer em Jacques Rancière, a "semelhança" explode meio século antes do advento das vanguardas históricas com a emergência do realismo, não seria preciso rever a noção de naturalismo como fantasmagoria? Em outros termos, se a mímesis cai ainda no século XIX, não seria necessário revisitar seus cronotopos sob outras luzes? Isto quanto ao século $X I X$. Porque, em relação ao século $X X$, o fantasma naturalistadocumentalista permanece vivo e ativo tanto no que diz respeito a sua produção discursiva quanto a sua recepção crítica. O que se comprova, ainda no início do século XXI, com a invocação e execração sintomática que dele segue fazendo Flora Süssekind, praticamente nos mesmos termos com que o imaginava a colega e conviva Ana Cristina César. Posto que, visto desse ângulo o problema, literatura não é documento e ponto final.

\section{$* * *$}

Hora de invocar e celebrar as epígrafes deste escrito, que é onde Ana C. e Flora S. parecem melhor se encontrar: no ensaio Até segunda ordem não me risque nada (1989). Posto que ali "não se trata de quebrar lanças mais uma vez por um 'biográfico, demasiado biográfico' ou por um 'literário, apenas literário'": não é mais questão de um ou outro, mas de um e outro, "ser e não ser" como no "Pós-poema" de Murilo Mendes décadas antes; ou, segundo a des-figuração de Ana Cristina César em "meu retrato buraco na parede" (retomando o último verso do "Poema" de João Cabral, "meu retrato eu morto"), poema por sinal desentranhado dos "cadernos, rascunhos e a poesia-em-vozes" de Ana C. por meio das artes crítico-poéticas de Flora S.

\section{Referências}

CÉSAR, Ana Cristina. Crítica e tradução. Literatura não é documento/Escritos no Rio/Escritos na Inglaterra/Alguma poesia traduzida. São Paulo: Ática, 1999a.

Correspondência incompleta. Rio de Janeiro: Aeroplano, 1999b.

FOUCAULT, Michel. A arqueologia do saber. 4. ed. Rio de Janeiro: Forense Universitária, 1995.

JAKOBSON, Roman et al. Do realismo artístico. In: Teoria da literatura. Formalistas russos. Trad. de Ana Mariza Ribeiro Filipouski et al. Porto Alegre: Editora Globo, 1973.

LE GOFF, Jacques. Documento/Monumento. In: Enciclopédia Einaudi. V. 1 MemóriaHistória. Lisboa: Imprensa Nacional e Casa da Moeda, 1997, p. 95. 
MORICONI, Ítalo. Ana Cristina César. O sangue de uma poeta. Rio de Janeiro: Relume-Dumará/Prefeitura, 1996.

NICHOLS, Bill. Introdução ao documentário. Trad. De Mônica S. Martins. São Paulo: Papirus, 2005.

RANCIÈRE, Jacques. A partilha do sensível. Estética e política. Trad. de Monica Costa Netto. São Paulo: EXO Experimental/Editora 34, 2005.

SAER, Juan José. El concepto de ficción. Punto de Vista no 40, Buenos Aires, julio-setiembre 1991 .

SANTIAGO, Silviano. Singular e anônimo. Nas malhas da letra. Rio de Janeiro: Rocco, 2002.

SODRÉ, Nélson Werneck. O naturalismo no Brasil. 2. ed. Belo Horizonte: Oficina de Livros, 1992.

SÜSSEKIND, Flora. Tal Brasil, Qual romance? Uma ideologia estética e sua história: o naturalismo. Rio de Janeiro: Achiamé, 1984.

Deterritorialization and literary form: Brazilian contemporary literature and urban experience. In: www.brazil.ox.ac.uk/workingpapers/Sussekind34.pdf

Não basta. Argumento, Rio de Janeiro, out./nov. 2003.

Desterritorialização e forma literária. Literatura brasileira e experiência urbana. Literatura e Sociedade $n^{\circ}$ 8. São Paulo, 2005.

Até segunda ordem não me risque nada. Os cadernos, rascunhos e a poesia-em-vozes de Ana Cristina César. 2. ed. Rio de Janeiro: 7Letras, 2007.

ZOLA, Emile. Lettre à Valabrègue (1864). In: Le roman expérimental. Paris: GF Flammarion, 2006.

Title: ¿Tal Brasil, cual novela? Literatura no es documento. Sobre Ana Cristina César y Flora Süssekind

Abstract: Ana C. y Flora, compañeras y colegas de las aulas del universo académico carioca de la década de los setenta, las dos con un pie en la universidad y otro en el periodismo, son abordadas críticamente a partir de esta convivencia y de dos ensayos producidos en esa época, Literatura no es documento y Tal Brasil, cual novela?. Tratase por lo tanto de ponerlos en contraste y de tomar como planteo llave la noción de un teórico del cine según la cual toda narrativa fílmica -y por extensión toda narrativa - es un "documental".

Keywords: Crítica brasileña. Neonaturalismo. Neodocumentalismo. Flora Süssekind. Ana Cristina César. Literatura. Documental.

Recebido em: 09/10/2013. Aceito em 30/11/2013 